\title{
Citrate Synthase Activity in Escherichia coli Harbouring Hybrid Plasmids Containing the glt A Gene
}

\author{
By DAVID P. BLOXHAM,* CHRISTOPHER J. HERBERT, \\ SARBJIT S. NER AND W. TERENCE DRABBLE \\ Department of Biochemistry, University of Southampton, Southampton SO9 3TU, U.K.
}

(Received 15 October 1982)

\begin{abstract}
A hybrid plasmid, pDB2, was constructed by ligating a $3.24 \mathrm{~kb}$ EcoRI/HindIII fragment of the Escherichia coli chromosome into pBR322. This was used to transform a gltA mutant which was devoid of citrate synthase activity. The resultant strain expressed very high citrate synthase activity and this enabled a simplified purification of the homogeneous enzyme in high yield. The subunit $M_{\mathrm{r}}$ was estimated as $47000-49000$ by SDS gel electrophoresis, which closely resembles the eukaryotic form of the enzyme. Evidence for some conservation of sequence between the two proteins was revealed in the acid cleavage pattern at aspartyl-prolyl residues. In addition to coding for the structural gene for citrate synthase, the $3.24 \mathrm{~kb}$ EcoRI/HindIII fragment also retained the genetic structure necessary for control of enzyme synthesis since the expression of enzyme activity in the strain harbouring pDB2 was still subject to glucose repression.
\end{abstract}

\section{INTRODUCTION}

Citrate synthase [citrate oxaloacetate-lyase (CoA-acetylating); EC 4.1.3.7] catalyses the first reaction of the citric acid cycle and is generally assumed to be rate determining for the cycle (Krebs \& Lowenstein, 1960; Weitzman, 1981). Recently, both the complete amino acid sequence (Bloxham et al., 1981, 1982) and the X-ray crystal structure (Remington et al., 1982) of pig-heart citrate synthase have been solved. A number of interesting features emerge from these studies such as the presence of trimethyllysine in the sequence, the identification of potentially important residues for catalysis, and the postulation of a large conformational change in the protein during the catalytic cycle. A feature of the enzyme structure is that there are so many functional residues that quantitatively analysing their contribution to the different stages of the catalytic reaction may prove rather complex. An attractive approach would be to use directed mutation to produce selected amino acid substitutions within the enzyme. This does not seem very practicable for the eukaryotic system at this time; however, the identification of plasmids carrying the Escherichia coli citrate synthase gene has opened the possibility of further genetic studies.

Citrate synthase is located at $16.2 \mathrm{~min}$ on the $E$. coli chromosome linkage map (Ashworth et al., 1965). Guest (1981) screened a collection of isolates from the E. coli gene bank (Clarke \& Carbon, 1976) to identify clones corresponding to this region of the chromosome. Three plasmids (pLC26.17, pLC27.18 and pLC31.28) were identified which were capable of complementing citrate synthase deficiency in mutants, and which coded for the synthesis of enzyme in enhanced concentrations in the host strain. The original plasmids were relatively large $(16-26 \mathrm{~kb})$. Hence, we have sought to construct a smaller hybrid plasmid carrying the citrate synthase gene using pBR322 (Bolivar \& Backman, 1979) as a defined vector. This plasmid would then carry the $\beta$-lactamase gene which would simplify the selection of plasmidcarrying strains either by ampicillin resistance or by the presence of citrate synthase. We hope that a hybrid plasmid of this type might be advantageous in coding for elevated enzyme concentrations, in analysing structural features of the gene which control its expression, and in 
the production of specific mutations within the enzyme. Recently, Spencer \& Guest (1982) have described an alternative approach by cloning the glt $A$ gene into $\lambda$ vectors. This is especially useful in mapping further citric acid cycle enzymes.

\section{METHODS}

Bacteria. The citrate synthase mutant W620 (thi-1 pyrD36 gltA6 galK30 rpsL129) and strain JA200 $\left(\mathrm{F}^{+}\right.$, thr leu lacYI trp $\triangle E 5$ recAI) containing the plasmid pLC27.18 (Clark \& Carbon, 1976) were kindly provided by Professor J. R. Guest. Strain HB101 (Boyer \& Roulland-Dussoix, 1969) was used for high efficiency of transformation. The strains carrying the citrate synthase gene on plasmids were DB1000 [W620(pLC27.18)], DB1001 [W620(pDB1)] and DB1002 [W620(pDB2)]. Bacteria were routinely grown at $37^{\circ} \mathrm{C}$ in L broth containing $0 \cdot 1 \%(\mathrm{w} / \mathrm{v})$ glucose and $25 \mu \mathrm{g}$ ampicillin $\mathrm{ml}^{-1}$ for Apr strains (DB1001, DB1002). Transformants of W620 were selected by growth on minimal medium $\mathrm{E}$ of Vogel \& Bonner (1956) supplemented with $\left(1^{-1}\right)$ : glucose $(1 \mathrm{~g})$, thiamine $(5 \mathrm{mg})$, uracil $(35 \mathrm{mg})$, streptomycin sulphate $(200 \mathrm{mg})$ and ampicillin $(25 \mathrm{mg})$. The medium was solidified with $1.5 \%(\mathrm{w} / \mathrm{v})$ agar. Strain W620 would not grow in the presence of ampicillin or without glutamate $(2 \mathrm{mM})$. On the selection media described there was a pronounced lag in growth of transformants of W620 in the first two days after transformation and plates were usually analysed after $4 \mathrm{~d}$ growth.

Plasmid analysis. Plasmid DNA was routinely purified by the mini-plasmid procedure of Kado \& Liu (1981) which involves lysis of a small amount of cells $\left(0.25 \mathrm{~cm}^{2}\right.$ on an agar plate) in $100 \mu \mathrm{l}$ of $3 \%(\mathrm{w} / \mathrm{v})$ SDS and $50 \mathrm{~mm}-$ Tris (pH 12.6) at $55^{\circ} \mathrm{C}$ for $1 \mathrm{~h}$ followed by extraction with $100 \mu \mathrm{l}$ of chloroform/phenol $(1: 1, \mathrm{v} / \mathrm{v})$. To generate sufficient DNA for restriction analysis and transformation experiments, the scale of the experiment was increased 10 -fold. The aqueous phase $(\sim 400 \mu \mathrm{l})$ from the initial extraction was washed three times with diethyl ether. After the addition of $100 \mu 11.5 \mathrm{M}$-sodium acetate, DNA was precipitated at $-70^{\circ} \mathrm{C}$ with ethanol and collected by centrifugation at 12000 r.p.m. for $5 \mathrm{~min}$. The pellet was washed three times with $80 \%(\mathrm{v} / \mathrm{v})$ ethanol at $-70^{\circ} \mathrm{C}$. After vacuum drying, the pellet was dissolved in $50 \mu 110 \mathrm{mM}$-Tris/ $\mathrm{HCl}$ containing $1 \mathrm{mM}$-EDTA, pH $8 \cdot 0$. The yield was usually 3-10 $\mu \mathrm{g}$ DNA

DNA samples $\left(1-2 \mu \mathrm{g}\right.$ ) were digested with $E c o$ RI ( 3 units) and $H i n d I I I ~\left(3\right.$ units) for $3 \mathrm{~h}$ at $37^{\circ} \mathrm{C}$ in $25 \mu 150 \mathrm{mM}$ Tris $/ \mathrm{HCl}, \mathrm{pH} 7 \cdot 4$, containing $100 \mathrm{mM}-\mathrm{NaCl}$ and $10 \mathrm{~mm}-\mathrm{MgSO}_{4}$. The reaction was terminated by heating at $65^{\circ} \mathrm{C}$ for $5 \mathrm{~min}$. After alcohol precipitation, DNA $(1 \mu \mathrm{g})$ was mixed with $E c o$ RI/HindIII-cleaved pBR322 $(0.5 \mu \mathrm{g})$ in $100 \mu \mathrm{l} 20 \mathrm{~mm}$-Tris/ $\mathrm{HCl}, \mathrm{pH} 8$, containing $10 \mathrm{mM}-\mathrm{MgSO}_{4}, 1.5 \mathrm{mM}$-DTT, $2 \mathrm{~mm}$-ATP and 0.2 units of $\mathrm{T}_{4}$ ligase and the reaction was allowed to proceed for $18 \mathrm{~h}$ at $4{ }^{\circ} \mathrm{C}$. Transformation of $\mathrm{Ca}^{2+}$-competent $\mathrm{HB} 101$ or W620 was performed exactly as described by Davis et al. (1980).

DNA samples were electrophoresed on $0.8 \%$ agarose gels in $40 \mathrm{~mm}$-Tris/acetate buffer, $\mathrm{pH} 8.1$, containing $2 \mathrm{mM}$-EDTA, for $18 \mathrm{~h} \mathrm{at} 1.5 \mathrm{~V} \mathrm{~cm}^{-1}$. Plasmid and restriction fragment sizes were estimated using V517 standard plasmid markers (Macrina et al., 1978) and a HindIII digest of $\lambda$ (Davis et al., 1980), respectively.

Enzyme preparation, characterization and assay. Citrate synthase was assayed in $0.1 \mathrm{M}-\mathrm{Tris} / \mathrm{HCl}, \mathrm{pH} 8 \cdot 0$, containing $200 \mu \mathrm{M}$-acetyl CoA, $350 \mu \mathrm{M}$-oxaloacetate and $100 \mu \mathrm{M}$-5,5'-dithiobis(2-nitrobenzoate) by measuring the increase in absorbance at $412 \mathrm{~nm}$ (Srere, 1969). One unit of enzyme activity catalysed the formation of $1 \mu \mathrm{mol} \mathrm{CoASH} \min ^{-1}$ at $20^{\circ} \mathrm{C}$.

For growth experiments, $500 \mathrm{ml}$ of minimal medium $\mathrm{E}$ containing thiamin, uracil, ampicillin, acetate $\left(4 \cdot 1 \mathrm{~g} \mathrm{l}^{-1}\right)$ and glutamate $\left(0 \cdot 3 \mathrm{~g} \mathrm{l}^{-1}\right)$ was inoculated with $10 \mathrm{ml}$ of an overnight culture and incubated with shaking at $37^{\circ} \mathrm{C}$. At appropriate times, $50 \mathrm{ml}$ of culture was removed and the $A_{650}$ was recorded. Cells were harvested by centrifugation at $5000 \mathrm{~g}$ for $10 \mathrm{~min}$. The pellet was suspended in $4 \mathrm{ml} 20 \mathrm{mM}$-Tris/ $\mathrm{HCl}, \mathrm{pH} 8 \cdot 0$, containing $1 \mathrm{~mm}$ EDTA, $10 \mathrm{mM}-\mathrm{MgCl}_{2}$ and $0 \cdot 1 \mathrm{M}-\mathrm{KCl}$. Cells were sonicated using an MSE soniprep 150 at $6 \mu \mathrm{m}$ amplitude for 3 bursts of $1 \mathrm{~min}$ with $50 \mathrm{~s}$ intervals. After centrifugation at $25000 \mathrm{~g}$ for $15 \mathrm{~min}$, the supernatant fraction was assayed for enzyme activity and protein concentration (Bradford, 1976).

For enzyme preparation, 101 of medium used in growth experiments was inoculated with $100 \mathrm{ml}$ of an overnight culture and grown at $30^{\circ} \mathrm{C}$ for $40 \mathrm{~h}$ with forced aeration. The bacteria were collected by centrifugation at $5000 \mathrm{~g}$ for $20 \mathrm{~min}$. After washing the pellet with ice-cold water, the bacteria were resuspended in $200 \mathrm{ml}$ of the buffer described for sonication above. Sonication was performed in $40 \mathrm{ml}$ batches and the supernatant fraction was prepared as described above. The enzyme was purified through protamine sulphate treatment, ammonium sulphate precipitation and chromatography on DEAE-cellulose as described by Weitzman (1969). The pooled enzyme fraction was adjusted to $80 \%$ saturation with ammonium sulphate and collected by centrifugation at $20000 \mathrm{~g}$ for $10 \mathrm{~min}$. The pellet was dissolved in $2 \mathrm{ml} 20 \mathrm{~mm}$-Tris/HCl, pH $8 \cdot 0$, containing $1 \mathrm{mM}$-EDTA, dialysed against the same buffer and stored in $80 \%$ saturated ammonium sulphate.

Gel electrophoresis in SDS used the conditions described by Weber \& Osborn (1969). The conditions for enzyme reduction and carboxymethylation, hydroxylamine cleavage and acid cleavage have been described by Bloxham $e t$ al. (1982). 


\section{RESULTS AND DISCUSSION}

\section{Construction of a hybrid plasmid containing the citrate synthase structural gene}

Initially we confirmed by F-mediated conjugation that pLC27.18 complemented the citrate synthase (glt $A$ ) mutation of the recipient (W620) thus confirming the location of the citrate synthase gene on this plasmid as reported by Guest (1981). Plasmid DNA prepared from JA200(pLC27.18) was found to contain two plasmids of $16.6 \mathrm{~kb}$ and $6.8 \mathrm{~kb}$ respectively. The smaller plasmid was resistant to both $E c o$ RI and HindIII restriction endonucleases. The larger plasmid carried the citrate synthase gene, as transformation of the gltA mutant W620 and selection for growth in the absence of glutamate yielded a strain (DB1000) containing the $16.6 \mathrm{~kb}$ plasmid only.

Digestion of the $16.6 \mathrm{~kb}$ plasmid derived from DB1000 with EcoRI and HindIII yielded two fragments of $13.4 \mathrm{~kb}$ and $3.24 \mathrm{~kb}$ (Fig. 1). The smaller fragment contains the putative citrate synthase gene (Guest, 1981). Doubly digested plasmid was mixed with pBR322 cleaved at its single EcoRI and HindIII sites and the mixture was ligated with $\mathrm{T}_{4}$ ligase. The hybrid DNA mixture was used to transform $\mathrm{HB} 101$ and $\mathrm{Ap}^{\mathrm{r}} \mathrm{Tc}^{\mathrm{s}}$ colonies were selected 250 colonies $(\mu \mathrm{g} \text { DNA })^{-1}$ ]. Mini-plasmid preparations from 20 colonies were used for the determination of plasmid size. The majority (16) of these transformants contained a plasmid of $17-19 \mathrm{~kb}$ that clearly consisted of a hybrid of pBR322 and the $13.4 \mathrm{~kb}$ fragment. The remaining four transformants contained plasmids of from 6 to $9 \cdot 1 \mathrm{~kb}$. Although the presence of the $3 \cdot 24 \mathrm{~kb}$ fragment could be demonstrated by restriction analysis on three out of the four plasmids, we felt that the plasmid-directed synthesis of active citrate synthase was the only satisfactory criterion to locate the gene. The hybrid plasmids were used, therefore, to transform a citrate synthase mutant (W620). Fortunately W620 transforms quite adequately, with $12 \%$ of the efficiency of HB101. Transformants were selected for ampicillin and streptomycin resistance and then screened for the ability to grow in the absence of glutamate. Of the four hybrid plasmids, only one (from DB1001) gave rise to transformants using this procedure. Colonies from this selection were $\mathrm{Pyr}^{-}$showing that the W620 phenotype was retained.

Preparations of DNA from DB1001 revealed a single plasmid (pDB1) of $9 \cdot 1 \mathrm{~kb}$ (Fig. 1). The plasmid was treated with EcoRI and HindIII yielding the anticipated $4.4 \mathrm{~kb}$ (from pBR322) and $3.24 \mathrm{~kb}$ fragments. Unexpectedly, the plasmid also contained one extra HindIII site and liberated a $1.5 \mathrm{~kb}$ fragment on HindIII treatment alone (Fig. 1). The origin of this DNA segment from pLC27.18 was uncertain so it was removed from pDB1 as follows. Plasmid pDB1 DNA was cleaved with HindIII and then ligated with $\mathrm{T}_{4}$ ligase. The resultant product was used to transform W620, and $\mathrm{Ap}^{\mathrm{r}}$ colonies (DB1002) which grew in the absence of glutamate were selected [ 150 colonies $(\mu \mathrm{g} \text { pDB1 DNA })^{-1}$ ]. A total of 24 randomly chosen colonies were screened and were all found to contain a plasmid (pDB2) of $7.6 \mathrm{~kb}$. Restriction analysis (Fig. 2) showed single EcoRI and HindIII sites and fragments of 4.4 and $3.24 \mathrm{~kb}$ were released.

\section{Citrate synthase activity in strains carrying hybrid plasmids}

Enzyme activity was measured in strain DB1002 containing the hybrid plasmid pDB2 and compared with a number of other strains (Table 1). As originally observed by Guest (1981), strains containing the plasmid pLC27.18 (i.e. DB1000) have significantly higher activities of citrate synthase than wild-type strains (i.e. HB101). However, the expression of activity was amplified even further in strains carrying the hybrid plasmid derived from pBR322 (DB1001 or DB1002). The range of maximum specific activity that we observed in bacterial extracts was 68 units (mg protein $)^{-1}$ compared to 45 units (mg protein) $)^{-1}$ for the pure protein (Weitzman, 1969; see Table 2). Therefore, at the start of the stationary phase of bacterial growth citrate synthase accounts for about $14 \%$ of the total protein solubilized by sonication. In contrast, the glt $A$ mutant starting strain (W620) was virtually devoid of enzyme activity.

The high specific activity of citrate synthase in sonic extracts of DB1002 suggested that the enzyme should be easily purified from this source. We adapted a purification procedure which was developed for wild-type bacteria where isolation of homogeneous enzyme requires a 450 - 


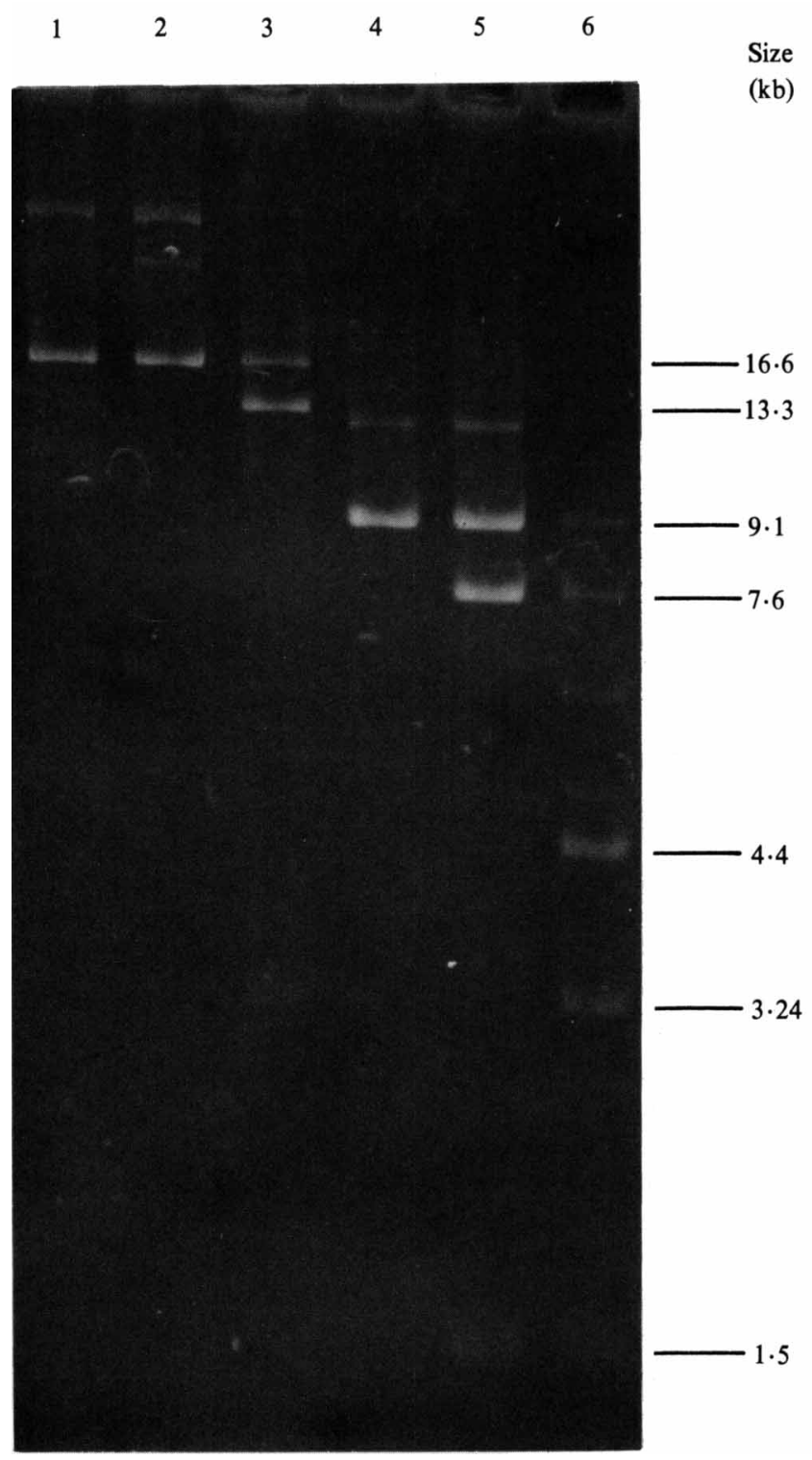

Fig. 1. Agarose gel electrophoresis of plasmid DNA samples. The following samples of DNA $(0 \cdot 5 \mu \mathrm{g})$ were analysed: 1, EcoRI-digested pLC27.18;2, HindIII-digested pLC27.18;3, HindIII/EcoRI-digested pLC27.18; 4, EcoRI-digested pDB1; 5, HindIII-digested pDB1; 6, HindIII/EcoRI-digested pDB1. The pLC27.18 DNA used in this experiment was derived from strain DB1000 [W620(pLC27.18)].

fold purification (Weitzman, 1969). For large-scale enzyme preparations we were forced to grow the bacteria at $30^{\circ} \mathrm{C}$ and this accounts for the decrease in specific activity compared to values reported in Table 1. The purification of enzyme from the plasmid-bearing strain resulted in $37 \%$ yield and required only part of the original procedure to produce homogeneous enzyme (Table 2 , Fig. 3). The enzyme eluting from the DEAE-cellulose column (Fig. 3) was divided into two major fractions. Analysis of the enzyme by SDS gel electrophoresis, using a continuous phosphate buffer system (Weber \& Osborn, 1969), revealed a molecular weight of around 47000-49000 and the bacterial enzyme was virtually indistinguishable from the pig-heart citrate synthase marker enzyme. Clearly the hybrid plasmid encodes the complete citrate synthase gene 


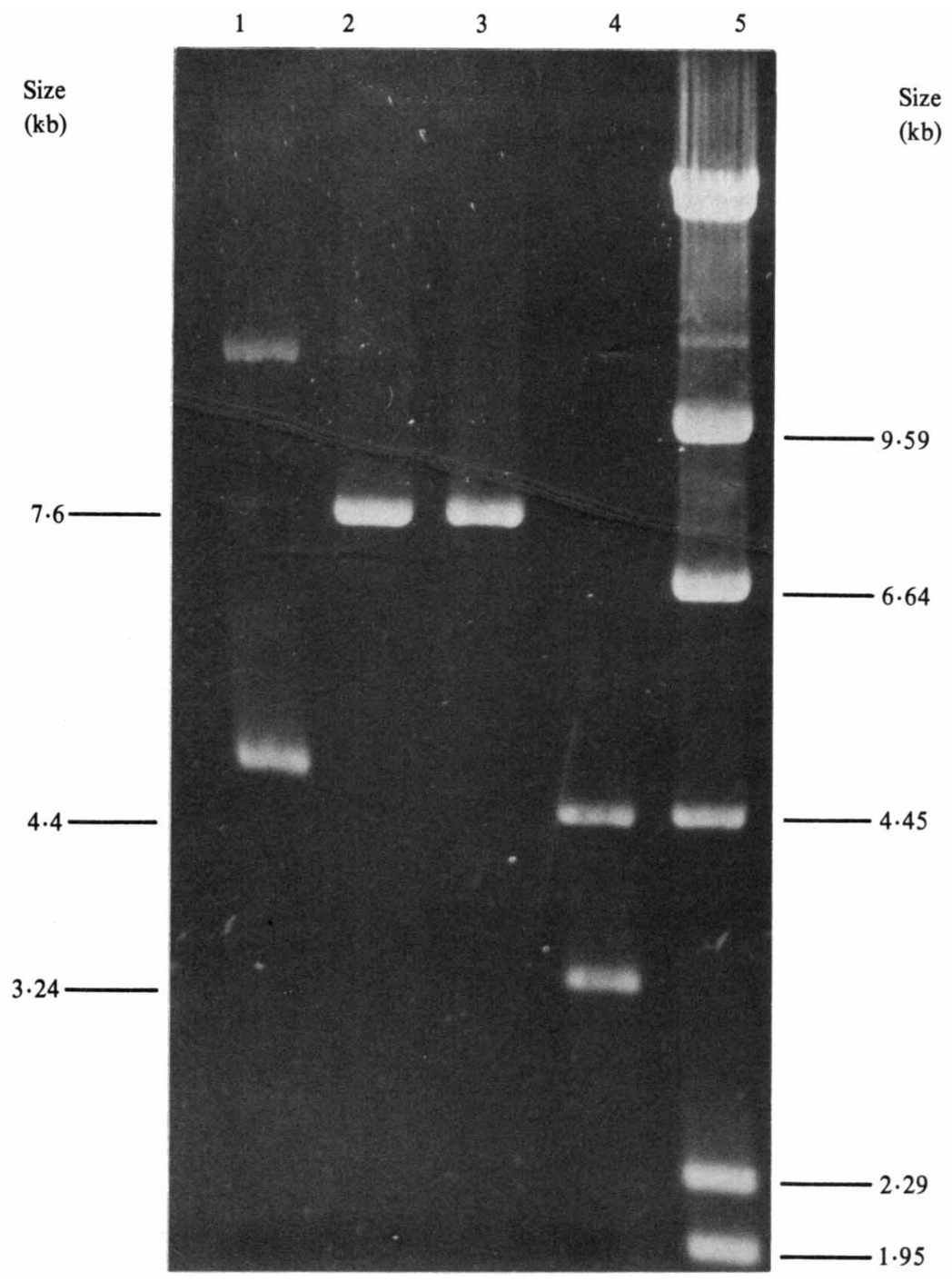

Fig. 2. Agarose gel electrophoresis of plasmid pDB2 DNA. The following samples of DNA $(\sim 0 \cdot 5 \mu \mathrm{g})$ were analysed: 1, pDB2; 2, HindIII-digested pDB2;3, EcoRI-digested pDB2; 4, HindIII/EcoRIdigested pDB2; 5, HindIII-digested $\lambda$ DNA.

Table 1. Expression of citrate synthase activity in bacterial strains

Cultures $(50 \mathrm{ml})$ of appropriate bacterial strains were grown for $7 \mathrm{~h}$ at $38^{\circ} \mathrm{C}$ in minimal salts medium containing acetate, glutamate, nutritional supplements (as appropriate) and ampicillin for Ap' strains. Enzyme activity and protein concentration were determined as described in Methods. Values are given \pm S.D.

\section{Enzyme activity}

Strain [units (mg total soluble protein $)^{-1}$ ]

W620

HB101

JA200(pLC27.18)

DB 1000

DB1001

DB1002
0

$0.15 \pm 0.05$

$2.5 \pm 0.4$

$2.5 \pm 0.5$

$6.7 \pm 0.7$

$7.0 \pm 1.0$ 


\section{Table 2. Purification of citrate synthase from DB1002}

The enzyme was purified from a 101 culture of DB1002. The details of the purification and assay are in Methods. The pooling of fractions A and B is shown in Fig. 3.

\begin{tabular}{|c|c|c|c|c|c|}
\hline Stage & $\begin{array}{l}\text { Volume } \\
\text { (ml) }\end{array}$ & $\begin{array}{l}\text { Total } \\
\text { enzyme activity } \\
\text { (units) }\end{array}$ & $\begin{array}{l}\text { Total amount } \\
\text { of protein } \\
(\mathrm{mg})\end{array}$ & $\begin{array}{c}\text { Specific } \\
\text { activity } \\
\text { [units }(\mathrm{mg} \text { protein })^{-1} \text { ] }\end{array}$ & $\begin{array}{c}\text { Yield } \\
(\%)\end{array}$ \\
\hline Sonic extract & 250 & 5940 & 1856 & $3 \cdot 2$ & 100 \\
\hline Protamine sulphate & 260 & 4060 & 1270 & $3 \cdot 2$ & $68 \cdot 3$ \\
\hline Ammonium sulphate & & & & & \\
\hline (55-70\% saturation) & 22 & 3830 & 222 & $17 \cdot 2$ & $64 \cdot 4$ \\
\hline DEAE-cellulose (fraction A) & $3 \cdot 3$ & 1560 & 35 & $45\}$ & \\
\hline DEAE-cellulose (fraction B) & $1 \cdot 4$ & 630 & 15 & $42\}$ & 36.9 \\
\hline
\end{tabular}

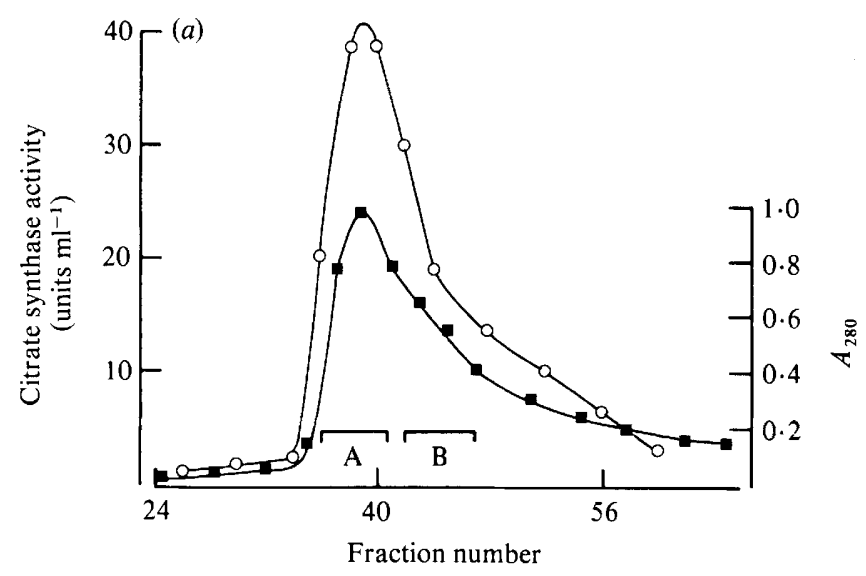

Fig. 3. Homogeneity of citrate synthase purified from DB1002. (a) An elution profile of citrate synthase from a DEAE-cellulose column $(15 \times 6 \mathrm{~cm})$ after washing exhaustively with $20 \mathrm{~mm}$-Tris/ $\mathrm{HCl}, \mathrm{pH} 8$, containing $0 \cdot 1 \mathrm{M}-\mathrm{KCl}$ and $1 \mathrm{~mm}-\mathrm{EDTA}$. The enzyme was eluted with the same buffer containing $0.15 \mathrm{M}-\mathrm{KCl}$ (fraction volume $6.5 \mathrm{ml}$ ). $\mathrm{O}$, Citrate synthase activity; $\boldsymbol{\square}, \boldsymbol{A}_{280} .(b)$ SDS gel electrophoresis profile of the following protein samples: $1,50 \mu \mathrm{g}$ fraction $\mathrm{A} ; 2,25 \mu \mathrm{g}$ fraction $\mathrm{B} ; 3$, standards. The standard marked with an arrow is pig-heart citrate synthase.

in the $3.24 \mathrm{~kb}$ fragment, and enzyme activity is not the result of complementation between two polypeptides encoded by W620 genomic DNA and the plasmid DNA.

Many previous estimates of molecular weight have suggested that the prokaryotic citrate synthase subunit is larger than the eukaryotic form (reviewed by Weitzman \& Danson, 1976) and implied that there is a substantial structural difference between the two enzyme forms. However, the running gel used in gel electrophoresis was frequently more complex than the system used in Fig. 3, suggesting that many previous molecular weight estimates might be anomalous. Certainly, Tong \& Duckworth (1975) using the same electrophoretic system as in Fig. 3 suggested that for acetate-grown $E$. coli the subunit molecular weight was 47000 and the native form of the enzyme was a hexamer.

The observation that the molecular weights of the two forms were similar prompted us to investigate whether there was any evidence for sequence homology between the two forms. During the determination of the sequence of pig-heart citrate synthase, two diagnostic cleavage reactions were described with hydroxylamine at the single Asn267-Gly268 bond, and acid at the four aspartyl-prolyl bonds 59-60, 257-258, 327-328 and 344-345 (Bloxham et al., 1981, 1982). These cleavages were repeated with the plasmid-encoded enzyme (Fig. 4). Hydroxylamine cleavage yielded a total of three main polypeptide bands with molecular weight 37600,23400 and 9000-10000. This cleavage pattern is clearly different from the result with the pig-heart enzyme and demonstrates that the structures of the two enzymes are not strictly homologous. In 




Fig. 4. Fragmentation of carboxymethylated E. coli citrate synthase. Citrate synthase was cleaved either with acid at aspartyl-prolyl bonds (track 1) or with hydroxylamine at asparaginyl-glycyl bonds (track 2) and the products were analysed by SDS gel electrophoresis. The arrows indicate the protein bands observed when the same cleavage reactions were performed with pig-heart citrate synthase.

contrast, the acid cleavage pattern was remarkably similar between the two enzyme forms, indicating that the number of aspartyl-prolyl bonds along the sequence of the prokaryotic enzyme must resemble that found in the pig-heart enzyme. The major polypeptides from the prokaryotic enzyme showed molecular weights of $43800,38000,28800,19800,12200$ and 9300 . Therefore we may anticipate regions of sequence homology between the two proteins.

\section{Repression of citrate synthase by glucose}

The inclusion of glucose in the growth medium of wild-type bacteria usually decreases the concentration of citrate synthase and other enzymes of the citric acid cycle (Gray et al., 1966; Flechtner \& Hanson, 1969). Having established that the hybrid plasmid, pDB2, carries the complete structural gene for citrate synthase we decided to investigate whether repression of enzyme synthesis was also retained.

DB1002 was grown on minimal salts medium containing acetate and glutamate in the presence or absence of glucose. Although glutamate is not required for growth of DB1002 it was 


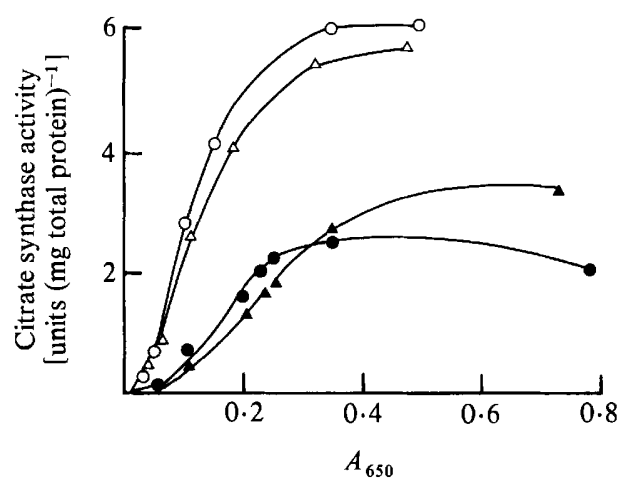

Fig. 5. Glucose repression of citrate synthase synthesis in DB1002. Bacteria were grown on acetate and glutamate as described in Methods, with the following further additions: $\bigcirc$, none; $\bigcirc$, glucose; $\triangle$, ampicillin; $\boldsymbol{\Delta}$, glucose plus ampicillin. At various times from 0 to $18 \mathrm{~h}$ cells were analysed for growth by measuring absorbance at $650 \mathrm{~nm}$ and enzyme activity was determined in sonic extracts of the harvested bacteria.

included to increase the total cell yield. The inclusion of glucose in the medium resulted in a decreased production of citrate synthase (Fig. 5). This was observed both as a decrease in the final specific activity of citrate synthase in stationary phase bacteria and as a slower increase in enzyme specific activity during the exponential growth phase. Glucose repression was also demonstrated in a completely analogous manner when bacteria were grown on complex media such as LB medium or 2TY medium. The preceding experiment establishes that the $3.24 \mathrm{~kb}$ insert retains the genetic structure necessary for glucose repression. The presence of ampicillin had virtually no effect on the production of citrate synthase by DB1002 (Fig. 5). This indicates that the plasmid is stable in this bacterial strain and does not require maintenance of selective pressure.

This work was supported by project grant GR/B/82639 from the Science and Engineering Research Council.

\section{REFERENCES}

Ashworth, J. M., Kornberg, H. L. \& Nothmann, D. L. (1965). Location of the structural gene for citrate synthase on the chromosome of Escherichia coli $\mathrm{K} 12$. Journal of Molecular Biology 11, 654-657.

Bloxham, D. P., Parmelee, D. C., Kumar, S., Wade, R. D., Ericsson, L. H., Neurath, H., Walsh, K. A. \& TITANI, K. (1981). Primary structure of porcine heart citrate synthase. Proceedings of the National Academy of Sciences of the United States of America 78, 5381-5385.

Bloxham, D. P., Parmelee, D. C., Kumar, S., Walsh, K. A. \& Titani, K. (1982). Complete amino acid sequence of porcine heart citrate synthase. Biochemistry 21, 2028-2036.

Bolivar, F. \& Backman, K. (1979). Plasmids of Escherichia coli as cloning vectors. Methods in Enzymology 68, 245-280.

BOYER, H. W. \& Roulland-Dussoix, D. (1969). A complementation analysis of the restriction and modification of DNA in Escherichia coli. Journal of Molecular Biology 41, 459-472.

BRADFORD, M. M. (1976). A rapid and sensitive method for the quantitation of microgram quantities of protein utilising the principle of protein-dye binding. Analytical Biochemistry 72, 248-254.
Clarke, L. \& Carbon, J. (1976). A colony bank containing synthetic ColEl hybrid plasmids representative of the entire $E$. coli genome. Cell 9, 9199.

Davis, R. W., Botstein, D. \& Roth, J. R. (1980). Advanced Bacterial Genetics. Cold Spring Harbor, New York: Cold Spring Harbor Laboratory.

FLeChTNER, V. R. \& HANSON, V. R. (1969). Coarse and fine control of citrate synthase from Bacillus subtilis. Biochimica et biophysica acta 184, 252-262.

Gray, C. T., WimpenNy, J. W. T. \& Mossman, M. R. (1966). Effects of aerobiosis, anaerobiosis and nutrition on the formation of Krebs cycle enzymes in Escherichia coli. Biochimica et biophysica acta 117, 33 41.

GuEST, J. R. (1981). Hybrid plasmids containing the citrate synthase gene $(\mathrm{g} / \mathrm{t} A)$ of Escherichia coli $\mathrm{K} 12$. Journal of General Microbiology 124, 17-23.

KaDO, C. I. \& LIU, S. T. (1981). Rapid procedure for detection and isolation of large and small plasmids. Journal of Bacteriology 145, 1365-1373.

KReBs, H. A. \& Lowenstein, J. M. (1960). The tricarboxylic acid cycle. In Metabolic Pathways, pp. 129203. Edited by D. M. Greenberg. New York: Academic Press. 
Macrina, F. L., Kopecko, D. J., Jones, K. R., Ayers, D. J. \& MCCOWEN, S. M. (1978). A multiple plasmid-containing Escherichia coli strain: convenient source of size reference plasmid molecules. Plasmid 1, 417-420.

Remington, S., Wiegand, G. \& Huber, R. (1982). Crystallographic refinement and atomic models of two different forms of citrate synthase at 2.7 and $1.7 \AA$ resolution. Journal of Molecular Biology 158, $111-152$

SPENCER, M. E. \& GUest, J. R. (1982). Molecular cloning of four tricarboxylic acid genes of Escherichia coli. Journal of Bacteriology 151, 542-552.

SRERE, P. A. (1969). Citrate synthase. Methods in Enzymology 13, 3-11.

TonG, E. K. \& Duckworth, H. (1975). The quarternary structure of citrate synthase from Escherichia coli K12. Biochemistry 14, 235-241.
Vogel H. \& BonNer, D. M. (1956). A convenient growth medium for $E$. coli and some other microorganisms. Microbial Genetics Bulletin 13, 43-44.

WEBER, K. \& OsBORN, M. (1969). The reliability of molecular weight determinations by dodecyl sulfatepolyacrylamide gel electrophoresis. Journal of Biological Chemistry 244, 4406-4412.

Weitzman, P. D. J. (1969). Citrate synthase from Escherichia coli. Methods in Enzymology 13, 22-26.

WeITzMan, P. D. J. (1981). Unity and diversity in some bacterial citric acid-cycle enzymes. Advances in Microbial Physiology 22, 185-244.

Weitzman, P. D. J. \& Danson, M. J. (1976). Citrate synthase. Current Topics in Cell Regulation 10, 161204. 